\title{
Erratum to: treatment of 5 dogs with immune-mediated thrombocytopenia using romiplostim
}

\author{
Barbara Kohn ${ }^{1}$, Gürkan Bal ${ }^{2}$, Aleksandra Chirek${ }^{1}$, Sina Rehbein ${ }^{1}$ and Abdulgabar Salama ${ }^{2 *}$
}

\section{Erratum:}

n.b. The errors and associated corrections described in this document concerning the original manuscript were accountable to the production department handling this manuscript, and thus are no fault of the authors of this paper. Additionally, the online manuscript has now been updated with these corrections accordingly.

- The original version of the manuscript [1] contained incorrectly formatted data in Table 2, rendering the numerical data in the sub-columns "Day" and "Platelets Count" nonsensical. The formatting of Table 2 has now been adjusted to display the appropriate numerical values in each cell more accurately.

\section{Author details}

${ }^{1}$ Small Animal Clinic, Veterinary Medicine at the Freie Universität Berlin, Oertzenweg 19b, Berlin 14163, Germany. ${ }^{2}$ Institute of Transfusion Medicine, Charité - Universitätsklinikum Berlin, Augustenburger Platz 1, Berlin 13353, Germany.

Received: 26 July 2016 Accepted: 27 July 2016

Published online: 30 December 2016

\section{Reference}

1. Kohn B, Bal G, Chirek A, Rehbein S, Salama A. Treatment of 5 dogs with immune-mediated thrombocytopenia using romiplostim. BMC Vet Res. 2016;12:96. http://doi.org/10.1186/s12917-016-0718-4.

\footnotetext{
* Correspondence: abdulgabar.salama@charite.de

${ }^{2}$ Institute of Transfusion Medicine, Charité - Universitätsklinikum Berlin, Augustenburger Platz 1, Berlin 13353, Germany

Full list of author information is available at the end of the article
}

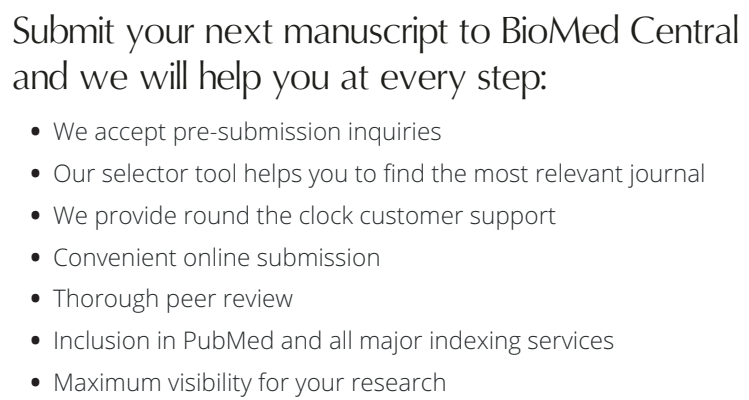

- We accept pre-submission inquiries

- Our selector tool helps you to find the most relevant journal

- We provide round the clock customer support

- Convenient online submission

- Thorough peer review

- Inclusion in PubMed and all major indexing services

- Maximum visibility for your research

Submit your manuscript at www.biomedcentral.com/submit 